\title{
Emerging vesiculo-type virus infections of freshwater fishes in Europe
}

\author{
A. M. Betts ${ }^{1}$, D. M. Stone ${ }^{1, *}$, K. Way $^{1}$, C. Torhy $^{2}$, S. Chilmonczyk ${ }^{2}$, A. Benmansour ${ }^{2}$, \\ P. de Kinkelin ${ }^{2}$
}

\footnotetext{
${ }^{1}$ Centre for the Environment, Fisheries and Aquaculture Science (CEFAS), Barrack Road, Weymouth, Dorset DT4 8UB, UK

${ }^{2}$ Institut National de la Recherche Agronomique (INRA), Unité de Virologie et d'Immunologie Moléculaires, Pathologie Infectieuse et Immunité des Poissons, 78352 Jouy-en-Josas Cedex, France
}

\begin{abstract}
Rhabdoviruses were isolated from perch Perca fluviatilis and largemouth bass Micropterus salmoides exhibiting clinical signs of disease. Preliminary studies indicated that these viruses could be neutralised by antisera to perch rhabdovirus (Dorson et al. 1984) and may be similar to those previously isolated from grayling Thymallus thymallus and pike-perch Stizostedion stizostedion. The relationship between these viruses and the previously characterised fish rhabdoviruses, pike fry rhabdovirus (PFRV), spring viraemia of carp virus (SVCV) and lake trout rhabdovirus, was investigated. Viruses were propagated in bluegill fry (BF-2) cells and were characterised using electron microscopy, serum neutralisation tests, immunofluorescence tests, sodium dodecyl sulfate polyacrylamide gel electrophoresis (SDS-PAGE) and nucleotide sequence analysis. The bullet-shaped viral particles appeared to be compact, with spikes visible at the surface, a morphology similar to that of the vesiculovirus group of rhabdoviruses. Serum neutralisation tests showed that the viruses were antigenically closely related to the previously characterised perch rhabdovirus, but were not significantly neutralised by antisera to PFRV, SVCV or viral haemorrhagic septicaemia virus (VHSV). In immunofluorescence tests with perch rhabdovirus antisera, strong specific fluorescence was observed in cell cultures infected with the new rhabdovirus isolates, but no fluorescence was observed with antisera to PFRV, SVCV or VHSV. SDS-PAGE analysis revealed a polypeptide profile typical of vesiculoviruses, but the novel virus isolates had different relative mobilities of their $\mathrm{P}$ and M proteins compared to PFRV and SVCV. Nucleotide sequence analysis was carried out using reverse transcriptase-polymerase chain reaction (RT-PCR) and DNA sequencing of a 439 base-pair region of the viral $\mathrm{L}$ gene. The novel rhabdovirus isolates had $<76 \%$ nucleotide sequence identity to PFRV, SVCV and lake trout rhabdovirus and $>95 \%$ identity to perch rhabdovirus. Phylogenetic analysis using both maximum parsimony and neighbour-joining methods assigned the perch rhaboviruses to a separate group to that of PFRV, SVCV and lake trout rhabdovirus. These data are the initial characterisation of a group of emerging fish vesiculo-type viruses that are biochemically and genetically distinct from the PFRV, SVCV and lake trout rhabdoviruses.
\end{abstract}

KEY WORDS: Fish $\cdot$ Rhabdovirus $\cdot$ Percids $\cdot$ Centrarchids $\cdot$ Thymallids $\cdot$ Antigenicity $\cdot$ Proteins $\cdot$ L gene

\section{INTRODUCTION}

The development of intensive aquaculture has favoured the emergence of viruses pathogenic for a number of cultured fish species. As the number of species being cultured has increased, so the number and variety of emerging viruses detected in these fishes has also increased (Castric 1997). Viruses in the families Birnaviridae, Herpesviridae, Iridoviridae, Orthomyxoviridae, Picornaviridae and Reoviridae have all been isolated from cultured fish species (Wolf 1988, Hetrick \& Hedrick 1993). However, the viruses that have emerged as having the most serious socio-economic impact on aquaculture are the rhabdoviruses, in par- 
ticular, the novirhabdoviruses viral haemorrhagic septicaemia virus (VHSV) and infectious haematopoietic necrosis virus (IHNV) in trout and other salmonids and the vesiculo-type virus causing spring viraemia of carp (SVCV). These viruses are all responsible for major disease epizootics in cultured populations and are notifiable to the Office International des Epizooties (OIE).

The SVC virus was first isolated from carp in Yugoslavia in the early 1970s (Fijan et al. 1971) and was followed by isolations in countries elsewhere in Europe during the 1970s and 1980s, including Czechoslovakia, Hungary and the UK (Wolf 1988). The early 1970s also saw the isolation and characterisation of another vesiculo-type virus, pike fry rhabdovirus (PFRV), the causative agent of red disease of pike (Kinkelin et al. 1973), and until 1981 PFRV and SVCV were the only known vesiculo-type viruses responsible for disease epizootics in cultured fishes. In 1981, a rhabdovirus failing to grow in the Epithelioma papulosum cyprini (EPC) cell line and antigenically distinct from the other then known fish rhabdoviruses was isolated from encephalons of perch Perca fluviatilis. The perch originated from a pond fish-farm in the central area of France and exhibited spinning movements while swimming (Dorson et al. 1984). This virus was designated perch rhabdovirus and was first demonstrated to be pathogenic for its host species only after intracranial inoculation of cell culture-grown virus. However, perch rhabdovirus was found to produce septicaemic infections in juvenile pike Esox lucius, with mortality, via bath challenge (Dorson et al. 1987).

There were no other recorded outbreaks associated with perch rhabdovirus until 1990, when another rhabdovirus, antigenically similar to perch rhabdovirus, was recovered from pike-perch Stizostedion stizostedion larvae that had undergone total mortality (Nougayrède et al. 1992). These larvae were reared in a hatchery at a pond fish-farm in central France, but at a different site from that of the original isolation of perch rhabdovirus. Another rhabdovirus was also isolated in 1990, this time from diseased grayling Thymallus thymallus in a salmonid fish farm in the eastern area of France (M. Morand unpubl.). This virus could not be characterised by the anti-rhabdovirus rabbit antisera then available, and was thus stored at the INRA (Institut National de la Recherche Agronomique) until further characterisation could be made.

Then, 3 yr later, a rhabdovirus designated DK5533 was isolated from asymptomatic pike in Denmark (Jørgensen et al. 1993). This virus, which displayed a protein electropherogram typical of rhabdoviruses belonging to the genus Vesiculovirus, was found to be antigenically similar to perch rhabdovirus in immunofluorescence assays and was experimentally pathogenic for juvenile pike by water-borne infection. Anti- sera raised against DK5533 were also shown to crossreact with the lake trout rhabdovirus virus (903/87) isolated from brown trout Salmo trutta m. lacustris in northern Finland in 1987 (Koski et al. 1992, Jørgensen et al. 1993, Bjorklund et al. 1994).

In 1995, 2 further virus isolates were recovered from perch and largemouth bass at the INRA laboratory, Jouy-en Josas (this study). These viruses originated from the same farming site as that which had given rise to the pike-perch rhabdovirus isolate, and they were neutralised by a trout antiserum to perch rhabdovirus.

In 1996, the Swedish sea trout virus (SSTV) was isolated from sea trout Salmo trutta trutta from the archipelago of Stockholm, Sweden, and it was recently shown that this virus was gentically related to the lake trout rhabdovirus (Johansson et al. 2001). In 1997, the first isolation of a rhabdovirus from perch was made in Norway (Dannevig et al. 2001).

Preliminary studies suggested that the perch and largemouth bass isolates from 1995 and the grayling isolate from 1990 were antigenically related to the 1990 pike-perch isolate and the 1981 perch isolate. However, the biochemical and genetic relationships of these viruses to each other and to the PFRV, SVCV and lake trout groups remained unclear. Therefore, this study was initiated to characterise the perch, largemouth bass and grayling viruses isolated between 1990 and 1995 and to determine the relationship between these isolates and those previously isolated from pike-perch and perch. The gross clinical and pathological characteristics of the viruses were characterised-followed by a study of viral morphology, antigenicity, protein composition and genetic analysis based on partial RNA polymerase (L) gene sequences. The resulting data from these antigenic, biochemical and genetic studies have identified an emerging group of fish vesiculo-type viruses that are distinct from the PFRV, SVCV and lake trout rhabdovirus groups.

\section{MATERIALS AND METHODS}

Virus isolates. Table 1 shows the identity and origin of the virus isolates used. The PFRV, SVCV and VHSV isolates originated from the reference virus stocks of the INRA laboratory and were propagated in the Epithelioma papillosum cyprini (EPC) cell line (Fijan et al. 1983). The resulting infectious cell-culture fluids were clarified by centrifugation, filtered through $450 \mathrm{~nm}$ pore membranes (Minisart Sartorius), aliquoted into 2 and $0.2 \mathrm{ml}$ amounts, and stored frozen at $-80^{\circ} \mathrm{C}$. All the other virus isolates were passaged 3 times in BF-2 cells after their primary identification in cell culture. Perch rhabdovirus and Virus Isolates 47.90 and 48.90 had been originally isolated in the RTG-2 cell line. The 
Table 1. Virus isolates used. LDA: Laboratoire Départemental d'Analyses followed by name of Department; INRA: Institut National de la Recherche Agronomique; DVL: Danish National Veterinary Laboratory; CEFAS: Centre for Environment Fisheries and Aquaculture Sciences

\begin{tabular}{|c|c|c|c|c|}
\hline Virus name (abbreviation) & Virus strain & Isolation from & Virus supplier & Source \\
\hline Perch virus isolate & 02.95 & Perca fluviatilis & INRA & This study \\
\hline $\begin{array}{l}\text { Largemouth bass } \\
\text { virus isolate }\end{array}$ & 03.95 & Micropterus salmoides & INRA & This study \\
\hline Pike rhabdovirus & DK5533 & Esox lucius & $\begin{array}{l}\text { Olesen } \\
\text { DVL }\end{array}$ & $\begin{array}{l}\text { Jørgensen et al. } \\
\text { (1993) }\end{array}$ \\
\hline Pike-perch virus isolate & 48.90 & Stizostedion stizostedion & $\begin{array}{l}\text { Nougayrède } \\
\text { LDA Landes }\end{array}$ & $\begin{array}{l}\text { Nougayrède et al. } \\
\text { (1992) }\end{array}$ \\
\hline Grayling virus isolate & 47.90 & Thymallus thymallus & $\begin{array}{l}\text { Morand } \\
\text { LDA Jura }\end{array}$ & This study \\
\hline Perch rhabdovirus & No strain designation & Perca fluviatilis & INRA & Dorson et al. (1984) \\
\hline $\begin{array}{l}\text { Pike fry rhabdovirus } \\
\text { (PFRV) }\end{array}$ & PFRV & Esox lucius & INRA & $\begin{array}{l}\text { Kinkelin et al. } \\
\text { (1973) }\end{array}$ \\
\hline $\begin{array}{l}\text { Spring viraemia of } \\
\text { carp virus }\end{array}$ & No strain designation & Cyprinus carpio & Fijan & Fijan et al. (1971) \\
\hline Lake trout rhabdovirus & $903 / 87$ & Salmo trutte lucustris & CEFAS, Weymouth & Koski et al. (1992) \\
\hline $\begin{array}{l}\text { Viral haemorrhagic } \\
\text { septicaemia virus (VHSV) }\end{array}$ & 07.71 & Oncorhynchus mykiss & INRA & $\begin{array}{l}\text { Le Berre et al. } \\
(1977)\end{array}$ \\
\hline
\end{tabular}

Reference Virus Isolates PFRV, SVCV and VHSV were also propagated and titrated in BF-2 cells when required for comparative studies.

Cell cultures. The bluegill fry (BF-2) cell line (Wolf et al. 1966) was used for propagation and titration of all the viruses, as previous studies of perch rhabdovirus (Dorson et al. 1984), pike perch rhabdovirus (Nougayrède et al. 1992) and pike virus isolate DK5533 (Jørgensen et al. 1993) had established the lack of sensitivity of the EPC cell line. In addition, yields of these viruses were 20 times less from the rainbow trout gonad (RTG-2) cell line (Wolf \& Quimby 1962) than from BF-2 cells (P. de Kinkelin unpubl. data).

The BF-2 cell line was grown at $20^{\circ} \mathrm{C}$ in Stoker's medium, SM (Gibco Life Technology), a modification of Eagle's medium (Stoker \& MacPherson 1961), buffered at $\mathrm{pH} 7.4$ with $0.16 \mathrm{M}$ Tris- $\mathrm{HCl}$, and supplemented with $10 \%$ foetal bovine serum, $10 \%$ tryptose phosphate broth, penicillin (100 IU $\mathrm{ml}^{-1}$ ) and dihydrostreptomycin $\left(100 \mu \mathrm{g} \mathrm{ml}^{-1}\right)$. The serum concentration of SM was reduced to a maintenance level of $2 \%$ (SMM) for virus propagation and titration.

Virological examination. Fish tissues were minced with scissors, ground in a mortar with a pestle and quartz sand, diluted 1:10 in SM supplemented with antibiotics, and centrifuged for $20 \mathrm{~min}$ at $3000 \times g$ at $4^{\circ} \mathrm{C}$. Supernatants were incubated overnight at $4^{\circ} \mathrm{C}$ with antibiotics before being diluted in SMM and inoculated onto BF-2 cell monolayers at final dilutions of $1: 20,1: 100,1: 1000$ and 1:10000. Cell cultures were incubated at $15^{\circ} \mathrm{C}$ and examined daily for cytopathic effect (CPE). Identification of the virus isolates was performed using neutralisation and immunofluorescence tests.

Virus titration. The viruses were titrated by plaque assay on BF-2 cell monolayers grown in 12 well plates (Costar) and incubated at $15^{\circ} \mathrm{C}$ for 36 to $48 \mathrm{~h}$ with a semi-solid overlay of SMM $+0.75 \%$ of carboxymethyl cellulose (Sigma). The incubation medium was then withdrawn and the infected monolayers were fixed and stained with a $0.5 \%$ solution of crystal violet in $10 \%$ neutral buffered formalin. Plaques of around $1 \mathrm{~mm}$ in diameter were enumerated with a plaque reader at $10 \times$ magnification. The titres of the laboratory stocks of reference virus isolates PFRV, SVCV and VHSV were checked using BF-2 cells prior to the neutralisation and immunofluorescence tests.

Antisera. Trout antiserum to perch rhabdovirus was prepared previously (Dorson et al. 1984). Trout antiserum was used because, at the time, the available cell systems at INRA were unable to produce a sufficient amount of purified virus material for rabbit immunisation. We obtained 2 other trout antisera specific for Virus Isolates 47.90 (grayling) and 48.90 (pike perch) from $120 \mathrm{~g}$ trout held at $15^{\circ} \mathrm{C}$, intraperitoneally injected 3 times at $3 \mathrm{wk}$ intervals with $10^{6}$ plaqueforming units (pfu) of virus per fish. The immunised trout were bled $3 \mathrm{wk}$ after the last virus injection and the collected sera were heated at $45^{\circ} \mathrm{C}$ for $30 \mathrm{~min}$. After the neutralising activity of the sera had been tested, they were filtered through a $450 \mathrm{~nm}$ filter, aliquoted and frozen at $-20^{\circ} \mathrm{C}$. 
The rabbit antisera against PFRV, SVCV and VHSV were prepared at the INRA laboratory (Kinkelin et al. 1985). The rabbit antisera to DK5533 and perch rhabdovirus were raised and heat-inactivated at the Danish Veterinary Laboratory and kindly donated by N. J. Olesen.

Neutralisation tests. All serum neutralisation tests (SNT) were carried out on BF-2 monolayers grown in 24-well cell-culture plates (Costar). We mixed 2-fold dilutions of antiserum in SMM with an equal volume of virus suspension diluted in SMM to $40-150 \mathrm{pfu} \mathrm{ml}^{-1}$ and incubated this at $20^{\circ} \mathrm{C}$ for $1 \mathrm{~h}$. Any remaining infectivity was titrated by plaque assay as previously described. The neutralisation titre was expressed as the serum dilution producing a $50 \%$ reduction in virus plaques.

The SNT with trout antisera was conducted in the presence of rainbow trout complement (Dorson \& Torchy 1979), whereas the tests with rabbit antisera followed a similar method using rabbit complement. When reciprocal SNT could be conducted, the antigenic relationships between virus isolates were calculated by a modification of the method of Archetti \& Horsfall (1950), used by Hill \& Way (1995) in the serological classification of aquatic birnaviruses. The geometric mean of the neutralisation titre ratios $\left(\mathrm{r}^{*}\right)$ was derived from the equation $r^{*}=\sqrt{r_{1} \times r_{2}}$, where $r_{1}$ and $r_{2}$ are the $50 \%$ neutralisation titre ratios (homologous virus titre divided by heterologous virus titre) for a compared pair of viruses. In a reciprocal cross SNT, an $\mathrm{r}^{*}$ value of 1 indicates a high degree of antigenic relatedness, whereas $r$ values greater than 20 indicate a marked antigenic difference.

Immunofluorescence antibody test (IFAT). IFAT was performed with rabbit antisera previously absorbed with EPC and BF-2 cells according to the method of Jørgensen et al. (1993). BF-2 cell monolayers grown in 24-well cell-culture plates were inoculated with 100 to $200 \mathrm{pfu}$ virus well ${ }^{-1}$ and incubated for $36 \mathrm{~h}$ at $15^{\circ} \mathrm{C}$, then rinsed with phosphate buffered saline (PBS) and fixed with cold ethanol-acetone (1 vol:2 vol) for $20 \mathrm{~min}$ and air-dried. The fixed monolayers were treated for $1 \mathrm{~h}$ at $20^{\circ} \mathrm{C}$ with 2 -fold dilutions of primary antibody (rabbit antisera in PBS $+3 \%$ skimmed milk) and then rinsed with PBS. Fluorescein isothiocyanate-conjugated goat anti-rabbit antibody (Biosys) at the manufacturer's recommended dilution was then added and incubated for a further $1 \mathrm{~h}$ at $37^{\circ} \mathrm{C}$. After a further rinse with PBS, the culture wells were examined microscopically for specific fluorescence under UV illumination. Prior to carrying out IFAT on the new rhabdovirus isolates, optimal dilutions of the primary antibodies were determined against homologous virus for each of the antisera used.
Virus purification. Monolayers of BF-2 cells grown in $75 \mathrm{~cm}^{2}$ plastic flasks (Costar) were inoculated with each of the studied viruses ( 3 flasks per virus) at a multiplicity of infection of 0.05 pfu per cell and incubated at $15^{\circ} \mathrm{C}$ for 2 to $4 \mathrm{~d}$ until complete $\mathrm{CPE}$ was reached. The infectious cell-culture fluids from the flasks were then clarified by centrifugation at $4000 \times g$ for $40 \mathrm{~min}$ at $4^{\circ} \mathrm{C}$. We layered $23 \mathrm{ml}$ of infectious supernatant onto a $25 \%$ sterile glycerol cushion and ultracentrifuged at $130000 \times g$ for $90 \mathrm{~min}$ at $4^{\circ} \mathrm{C}$. The supernatant in each tube was aspirated, the tube wall carefully drained, and the resulting pellets resuspended in $200 \mu \mathrm{l} \mathrm{NaCl}$-Tris-EDTA buffer (TEN) (0.05 M Tris-HCl pH 7.6, $0.001 \mathrm{M}$ EDTA, $0.01 \mathrm{M} \mathrm{NaCl})$.

The quantity of protein in each purified virus preparation was determined according to the method of Bradford (1976) using a BioRad Protein Assay kit (BioRad) and was adjusted to $2 \mu \mathrm{g} \mathrm{ml}^{-1}$. The major part of each virus production $(80 \%)$ was used in SDS-PAGE studies and the remainder was used for electron microscopy.

Sodium dodecyl sulphate polyacrylamide gel electrophoresis (SDS-PAGE). Purified virus samples were mixed with an equal volume of double-strength Laemmli buffer (Laemmli 1970), heated for $5 \mathrm{~min}$ at $100^{\circ} \mathrm{C}$, dispensed in aliquots, and frozen at $-80^{\circ} \mathrm{C}$. SDS-PAGE was completed according to the method of Laemmli (1970) on $0.75 \mathrm{~mm}$ gels using the MiniProtean system (Bio-Rad) and Protogel (National Diagnostics). A $10 \%$ polyacrylamide separating gel with a $4 \%$ stacking gel was used. We loaded $5 \mu \mathrm{l}$ of thawed virus samples in Laemmli buffer into each preformed well, and the polypeptides were then separated by electrophoresis. A low molecular weight calibration kit (Amersham Pharmacia Biotec) was used as standard molecular weight markers. The gel was stained for $2 \mathrm{~h}$ in Coomassie Blue, and was subsequently destained until the viral polypeptides became visible.

Negative-contrast electron microscopy. Purified virus was diluted in distilled water and adsorbed to $1 \%$ bovine serum albumin-filmed, carbon-coated 400-mesh copper grids. The adsorbed material was then stained with $1.6 \%(\mathrm{w} / \mathrm{v})$ phosphotungstic acid and examined with a Philips CM 12 electron microscope at $80 \mathrm{kV}$.

Histology. From the same farming premises where Virus Isolates 02.95 and 03.95 had originated, we collected 2 perch of $3 \mathrm{~cm}$ in length from a cohort of fish that had undergone a recent severe mortality. These fish were euthanised with 2 phenoxyethanol (Prolabo) at 1:2500 and fixed for $3 \mathrm{~d}$ in neutral buffered formalin. After overnight rinsing in tap water, the fixed samples were processed for paraffin-embedding and sectioning at $5 \mu \mathrm{m}$. 
After de-paraffinisation, the sections were blocked with $3 \%$ skimmed milk in PBS, and incubated for $1 \mathrm{~h}$ at $37^{\circ} \mathrm{C}$ with rabbit antiserum to perch rhabdovirus diluted in PBS, pH 7.3, with $0.25 \%$ Triton X-100 (Koch-Light) and $0.1 \%$ Tween 20 . The primary antibody binding was revealed using a universal immunostaining kit incorporating a biotin-labelled anti-rabbit secondary antibody and streptavidin peroxidase with 3 amino-9-ethyl-carbazol (AEC) (Immunotech), according to the manufacturer's instructions. Tissue sections sampled from a healthy perch were also subjected to the immunostaining protocol as a negative control.

Reverse transcriptase-polymerase chain reaction (RT-PCR). Total RNA was extracted from virus-infected BF-2 cells using the Trizol reagent (BRL, Life Technologies) as described previously (Betts \& Stone 2000). Degenerate primers were designed to a highly conserved $485 \mathrm{bp}$ region of the viral RNA polymerase gene that contains polypeptide regions common to most members of the virus order Mononegavirales (Poch et al. 1990, Le Mercier et al. 1997). RNA (1 $\mu \mathrm{g}$ ) was reverse-transcribed in a $20 \mu \mathrm{l}$ reaction volume consisting of $1 \times$ M-MLV-RT (Moloney murine leukaemis virus reverse transcriptase) reaction buffer $(50 \mathrm{mM}$ Tris $\mathrm{pH}$ 8.3, $75 \mathrm{mM} \mathrm{KCl}, 10 \mathrm{mM}$ dithiothreitol, $3 \mathrm{mM}$ $\mathrm{MgCl}_{2}$ ), $1 \mathrm{mM}$ dNTP, $100 \mathrm{pmol}$ of Primer 1F (ATHATWGSHYTNAARSBVAARGA), 40 U RNAsin ribonuclease inhibitor (Promega) and $20 \mathrm{U}$ M-MLV-RT (Promega). Reactions were incubated at $37^{\circ} \mathrm{C}$ for $1 \mathrm{~h}$. PCR amplifications were performed in a $50 \mu \mathrm{l}$ reaction volume consisting of $1 \times$ PCR buffer $(50 \mathrm{mM} \mathrm{KCl}$, $10 \mathrm{mM}$ Tris- $\mathrm{HCl} \mathrm{pH}$ 8.3), 2 mM MgCl $2,200 \mu \mathrm{M}$ dNTPs, 100 pmol of Primer 1R (TGHCDBTRNCCTTCGADRCCNCC), 2.5 units of RedHot Taq polymerase (AB gene) and $5 \mu \mathrm{l}$ of reverse transcription reaction mix. The reaction mix was overlaid with mineral oil and subjected to 5 temperature cycles of $30 \mathrm{~s}$ at $94^{\circ} \mathrm{C}, 30 \mathrm{~s}$ at $42^{\circ} \mathrm{C}$ and $30 \mathrm{~s}$ at $72^{\circ} \mathrm{C}$ with the annealing temperature rising by $1^{\circ} \mathrm{C}$ per cycle, followed by 30 cycles of $30 \mathrm{~s}$ at $94^{\circ} \mathrm{C}, 30 \mathrm{~s}$ at $47^{\circ} \mathrm{C}$ and $30 \mathrm{~s}$ at $72^{\circ} \mathrm{C}$, followed by a final extension step of $10 \mathrm{~min}$ at $72^{\circ} \mathrm{C}$.

Aliquots $(10 \mu \mathrm{l})$ of the amplified products were electrophoresed in a $2 \%(\mathrm{w} / \mathrm{v})$ agarose/TAE (40 mM Trisacetate, $\mathrm{pH} 7.2,1 \mathrm{mM}$ EDTA) gel containing $1.0 \mu \mathrm{g}$ $\mathrm{ml}^{-1}$ ethidium bromide, and visualised by UV irradiation. PCR products were purified using the Geneclean III kit according to the manufacturer's protocol (Anachem) and cloned into the pGEM-T Easy vector (Promega) using the manufacturer's protocol.

DNA sequencing. At least 2 independent amplification and cloning events were performed for each of the virus isolates to eliminate potential errors introduced by the thermal stable polymerase and to identify the concensus sequence in what was likely to be a com- plex heterogeneous 'quasi-species'. Plasmid DNA was prepared using the alkaline lysis method as described previously (Sambrook et al. 1989) and both strands of the insert DNA were sequenced using the M-20 and reverse-sequencing primers (Stratagene) and the ABI PRISM BigDye terminator cycle sequencing system (Perkin Elmer). Sequencing reactions were analysed on an ABI 310 genetic analyser and multiple alignments were performed using Clustal V (Higgins \& Sharp 1989). Phylogenetic analysis was performed on the 439 bp partial L gene sequences using the maximum-parsimony and neighbour-joining DNA distance methods in the PHYLIP (Felsenstein 1989), using the phylogenic inference environment (PIE) facility at the Human Genome Mapping Project Resource Centre (HGMP-R), Hinxton, UK.

\section{RESULTS}

\section{Clinical background and virus isolation}

Virus Isolates 02.95 and 03.95 were recovered from diseased perch and largemouth bass, respectively, from indoor temperature-regulated premises intended for the rearing of several species of freshwater juvenile sport fishes in the centre of France.

Perch were mature specimens of 18 mo of age, some of which displayed a spinning locomotion alternating with lethargy. Largemouth bass were 7 mo old and behaved similarly to the perch. Prior to our visit to the farm, a cohort of perch alevins had undergone severe mortalities, the cohort but had subsequently recovered and only 2 overtly infected specimens were found to be suitable for histological examination.

The inoculation of BF-2 cells with pools of spleen and kidney tissues and encephalon from 3 individuals of the 2 fish species with nervous symptoms resulted in the onset of a CPE up to a dilution of 1:10 000. Infected cell cultures tested negative in IFAT with rabbit antisera to PFRV and SVCV, but isolated virus was neutralised by trout antisera to perch rhabdovirus at an antiserum dilution of 1:1000 (data not shown).

\section{Electron microscopy}

Virus Isolates 02.95, 03.95 and 47-90 were examined by electron microscopy (Fig. 1). After negative staining, the virus isolates all appeared as compact rhabdoviral particles of 85 to $95 \mathrm{~nm}$ in diameter and 115 to $130 \mathrm{~nm}$ in length (Fig. 1A-C). Spikes were visible at the surface of certain viral particles, and striations were seen in the nucleocapsid of others, depending on the degree of penetration of phosphotungstic acid. 

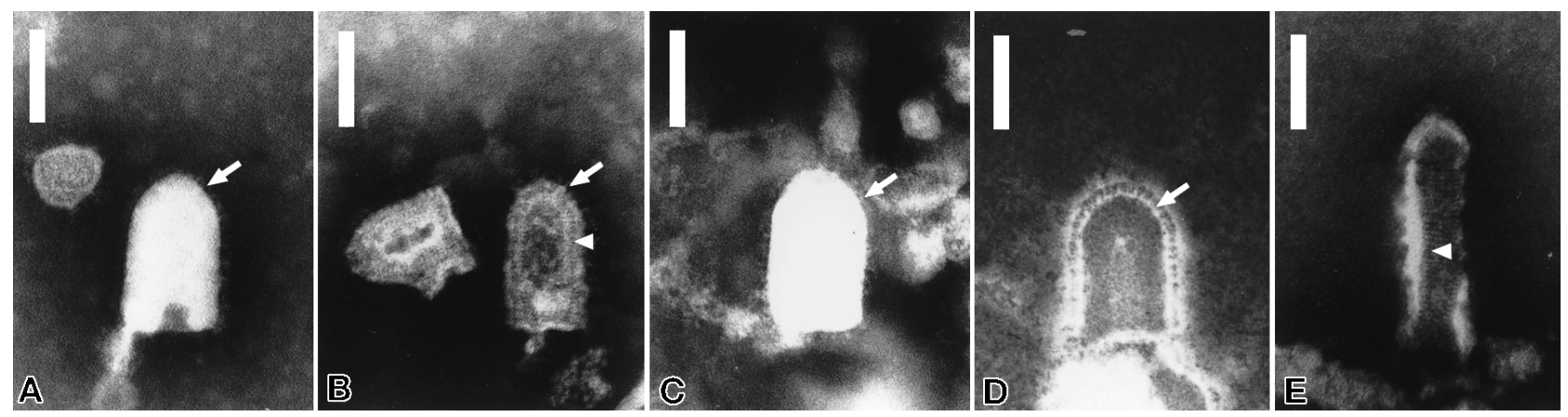

Fig. 1. Morphology of rhabdoviral particles. Transmission electron micrographs of negatively stained viral preparations. (A) Virus Isolate 02.95, (B) Virus Isolate 03.95 from largemouth bass, (C) Virus Isolate 47.90 from grayling, (D) spring viraemia of carp virus, (E) viral haemorrhagic septicaemia virus. Viruses display outer spikes (arrows) inserted in viral envelope and striated nucleocapsid (arrowheads). Scale bars $=100 \mathrm{~nm}$

This morphology was very similar to that of SVCV (Fig. 1D) which displayed morphology typical of vesiculoviruses. In contrast, VHSV (Fig. 1E) displayed the morphological characteristics of the genus Novirhabdovirus, in which the virus particles are longer and thinner than Vesiculovirus particles.

\section{Histology}

The histopathology was not dramatic in the 2 perch examined. The kidney tissue presented a small number of tubular destructions (Fig. 2A), but failed to react with antiserum to perch rhabdovirus in an immunoperoxidase test (data not shown). Some intermyoblastic haemorrhages were visible in some muscle tissue (Fig. 2B), and immunoperoxidase-labelled foci were infrequently seen in myoblasts (Fig. 2C). In the liver from 1 perch, a small number of hepatocytes tested immunoperoxidase-positive (Fig. 2D), whereas small foci of immunolabelling were present in some myocardic cells (Fig. 2E). No histopathological changes were observed in the nervous tissue. No immunolabelling was observed in tissues from the healthy perch (results not shown).

\section{Serum neutralisation tests}

The SNT conducted with rainbow trout antisera (Table 2) showed that perch rhabdovirus and Virus Isolates 47.90 and 48.90 were antigenically similar to each other $\left(\mathrm{r}^{*}\right.$ values ranging from 2.74 to 4.14$)$. Virus Isolate 03.95 was neutralised by all 3 antisera, but an $\mathrm{r}^{*}$ value was not calculated in the absence of homologous trout antiserum.

The SNT completed with rabbit antisera indicated that Rhabdovirus Isolates 47.90, 48.90, 02.95 and 03.95 were efficiently neutralised by antisera to perch rhab- dovirus and Isolate DK5533 (Table 3). Antisera to the reference virus isolates neutralised their respective homologous viruses. In contrast, PFRV, SVCV and VHSV viruses were not neutralised by perch rhabdovirus or DK5533 antisera, and the antisera to PFRV, SVCV and VHSV did not neutralise perch rhabdovirus or Isolate DK5533.

\section{Immunofluorescence tests}

Cell cultures infected with perch rhabdovirus and Isolate DK5533 showed strong, specific fluorescence in tests with homologous antiserum at titres of 1:800 and 1:400, respectively. Similarly, cultures infected with Isolates 47.90, 48.90, 02.95 and 03.95 also showed specific fluorescence with these antisera at titres of 1:200

Table 2. Antigenic relationships of rhabdoviruses using rainbow trout antisera in neutralisation tests. 50\% neutralising titres: serum titre reducing number of plaque forming units in a virus suspension by $50 \%$; virus titre adjusted to generate 100 plaques onto BF 2 cell monolayers grown in 24 -well tissue culture plates after $48 \mathrm{~h}$ incubation at $15^{\circ} \mathrm{C}$ under methylcellulose overlay. $r^{*}=\sqrt{r_{1} \times r_{2}}$, where $r_{1}$ and $r_{2}$ are the $50 \%$ neutralising titre ratios (homologous virus titre divided by heterologous virus titre for a compared pair of viruses). nd: no data $-r^{*}$ value was not calculated for Isolate 03.95 as the homologous titre was not available

\begin{tabular}{|c|c|c|c|c|}
\hline \multirow[t]{2}{*}{ Antisera } & \multicolumn{4}{|c|}{$\begin{array}{l}50 \% \text { neutralising titres and } \\
\left(\mathrm{r}^{*}\right) \text { values with Virus Isolate: }\end{array}$} \\
\hline & Perch rhabdovirus & 47.90 & 48.90 & 03.95 \\
\hline $\begin{array}{l}\text { Perch } \\
\text { rhabdovirus }\end{array}$ & $\begin{array}{l}20000 \\
(1)\end{array}$ & $\begin{array}{l}10000 \\
(3.16)\end{array}$ & $\begin{array}{l}10000 \\
(4.14)\end{array}$ & $\begin{array}{c}12000 \\
\text { (nd) }\end{array}$ \\
\hline 47.90 & 1000 & $\begin{array}{c}5000 \\
(1)\end{array}$ & $\begin{array}{l}4000 \\
(2.74)\end{array}$ & 1500 \\
\hline 48.90 & 700 & 4000 & $\begin{array}{c}6000 \\
(1)\end{array}$ & 1200 \\
\hline
\end{tabular}



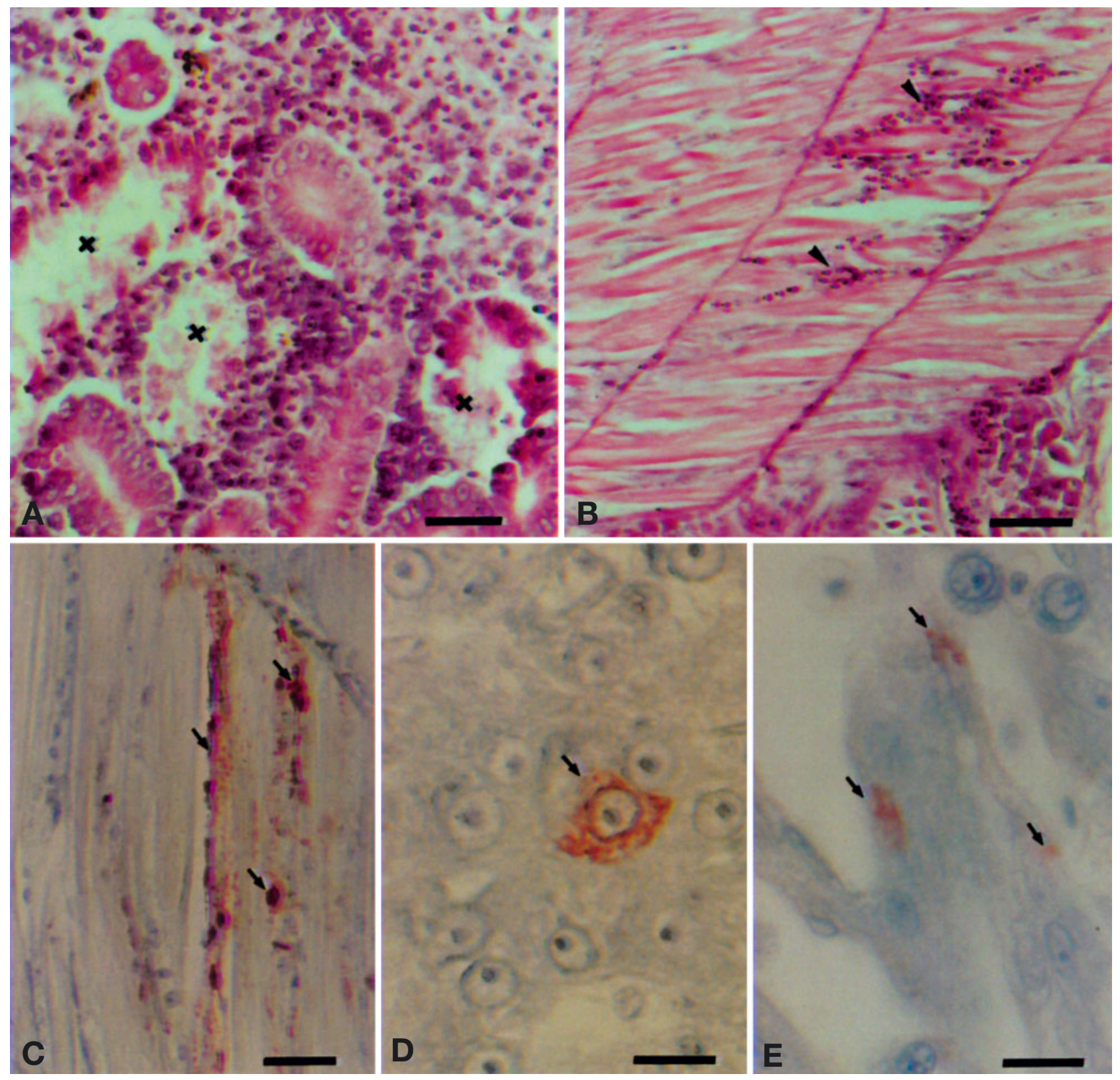

Fig. 2. Perca fluviatilis. Histopathology of infection in perch with Virus Isolate 02.95. Staining: (A,B) haematoxylin and eosin; (C-E) immunoperoxidase-AEC counterstained with haematoxylin. (A) Tubular nephritis resulting in necrosis of epithelial cells of the tubule ( $\mathbf{x})_{\text {; }}$ (B) myomer showing inter-myoblastic haemorrhages (arrowheads); (C) myomer with sites of immunoreactivity to virus isolate 02.95 in myoblasts (arrows); (D) liver presenting 1 immunopositive hepatocyte to Virus Isolate 02.95 (arrow); (E) myocard with 3 small areas of immunoreactivity to Virus Isolate 02.95 (arrows). Scale bar $=50 \mu \mathrm{m}$ in (A), $30 \mu \mathrm{m}$ in (B) and (C), $10 \mu \mathrm{m}$ in (D) and (E)

to 1:400. A cross-reaction between perch rhabdovirus antiserum and Isolate DK5533 and vice versa was also recorded. No fluorescence was observed in cultures infected with perch rhabdovirus, DK5533 or the novel rhabdovirus isolates in tests with antisera to PFRV, SVCV and VHSV. However, a cross-reaction between PFRV antisera and SVCV virus and vice versa was recorded (Table 4 ).

\section{SDS-PAGE}

Virus Isolates 47.90, 48.90, 02.95, 03.95 and perch rhabdovirus displayed the typical polypeptide profile of the rhabdoviruses belonging to the genus Vesiculovirus, characterised by PFRV (Fig. 3). The viral proteins, taken in order of decreasing molecular weights, were designated L, G, P (NS), N and M, respectively. By com- 
Table 3. Antigenic relationships of rhabdoviruses using rabbit antisera in neutralisation tests. Virus isolates abbreviated as in Table 1. <20: absence of neutralisation at serum dilution 1/20; further details as in legend to Table 2

\begin{tabular}{|c|c|c|c|c|c|c|c|c|c|}
\hline \multirow{2}{*}{ Antisera } & \multirow[b]{2}{*}{ Perch rhabdovirus } & \multicolumn{8}{|c|}{$50 \%$ neutralising titres and $\left(\mathrm{r}^{*}\right)$ values with Virus Isolate: } \\
\hline & & DK5533 & PFRV & SVCV & VHSV & 47.90 & 48.90 & 02.95 & 03.95 \\
\hline Perch rhabdovirus & $\begin{array}{c}3200 \\
(1)\end{array}$ & $\begin{array}{c}1600 \\
(\geq 1.4)\end{array}$ & $\begin{array}{l}<20 \\
(\geq 80)\end{array}$ & $\begin{array}{l}<20 \\
(\geq 89)\end{array}$ & $\begin{array}{c}<20 \\
(\geq 200)\end{array}$ & $\begin{array}{c}2000 \\
\text { (nd) }\end{array}$ & 2000 & 1600 & 1600 \\
\hline DK5533 & 300 & $\begin{array}{c}300 \\
(1)\end{array}$ & $\begin{array}{l}<20 \\
(\geq 24)\end{array}$ & $\begin{array}{l}<20 \\
(\geq 27)\end{array}$ & $\begin{array}{l}<20 \\
(\geq 61)\end{array}$ & 300 & 400 & 400 & 400 \\
\hline PFRV & $<20$ & $<20$ & $\begin{array}{c}800 \\
(1)\end{array}$ & $\begin{array}{l}<20 \\
(\geq 44)\end{array}$ & $\begin{array}{l}<20 \\
(\geq 100)\end{array}$ & $<20$ & $<20$ & $<20$ & $<20$ \\
\hline SVCV & $<20$ & $<20$ & $<20$ & $\begin{array}{c}1000 \\
(1)\end{array}$ & $\begin{array}{l}<20 \\
(\geq 111)\end{array}$ & $<20$ & $<20$ & $<20$ & $<20$ \\
\hline VHSV & $<20$ & $<20$ & $<20$ & $<20$ & $\begin{array}{c}5000 \\
(1)\end{array}$ & $<20$ & $<20$ & $<20$ & $<20$ \\
\hline
\end{tabular}

Table 4. Antigenic relationships of rhabdoviruses using rabbit antisera in indirect fluorescence antibody tests. Data are end point antiserum titres generating specific fluorescence response in cell cultures infected with different virus isolates (abbreviated as in Table 1). 100 to 200 plaque forming unit of virus well ${ }^{-1}$ were inoculated onto BF 2 cell monolayers grown in 24-well cell-culture plates and incubated at $15^{\circ} \mathrm{C}$ for $36 \mathrm{~h}$. 0 : absence of a fluorescent response at a serum dilution of $1 / 20$

\begin{tabular}{|c|c|c|c|c|c|c|c|c|c|}
\hline \multirow{2}{*}{ Antisera } & \multirow[b]{2}{*}{48.90} & \multirow[b]{2}{*}{47.90} & \multirow[b]{2}{*}{02.95} & \multirow[b]{2}{*}{03.95} & \multirow{2}{*}{$\begin{array}{l}\text { Virus Isolate: } \\
\text { Perch rhabdovirus }\end{array}$} & \multirow[b]{2}{*}{ DK5533 } & \multirow[b]{2}{*}{ PFRV } & \multirow[b]{2}{*}{ SVCV } & \multirow[b]{2}{*}{ VHSV } \\
\hline & & & & & & & & & \\
\hline Perch rhabdovirus & 200 & 400 & 400 & 400 & 800 & 800 & 0 & 0 & 0 \\
\hline DK5533 & 200 & 400 & 400 & 400 & 400 & 400 & 0 & 0 & 0 \\
\hline PFRV & 0 & 0 & 0 & 0 & 0 & 0 & 1000 & 1000 & 0 \\
\hline SVCV & 0 & 0 & 0 & 0 & 0 & 0 & 400 & 400 & 0 \\
\hline VHSV & 0 & 0 & 0 & 0 & 0 & 0 & 0 & 0 & 2000 \\
\hline
\end{tabular}

parison, VHSV featured the polypeptide profile of novirhabdoviruses, in which the P protein is located after the N protein. However, Virus Isolates 47.90, 48.90, 02.95, 03.95 and perch rhabdovirus formed a distinct electrophoretic entity from that displayed by PFRV (Fig. 3) and SVCV (data not shown), indicated by the

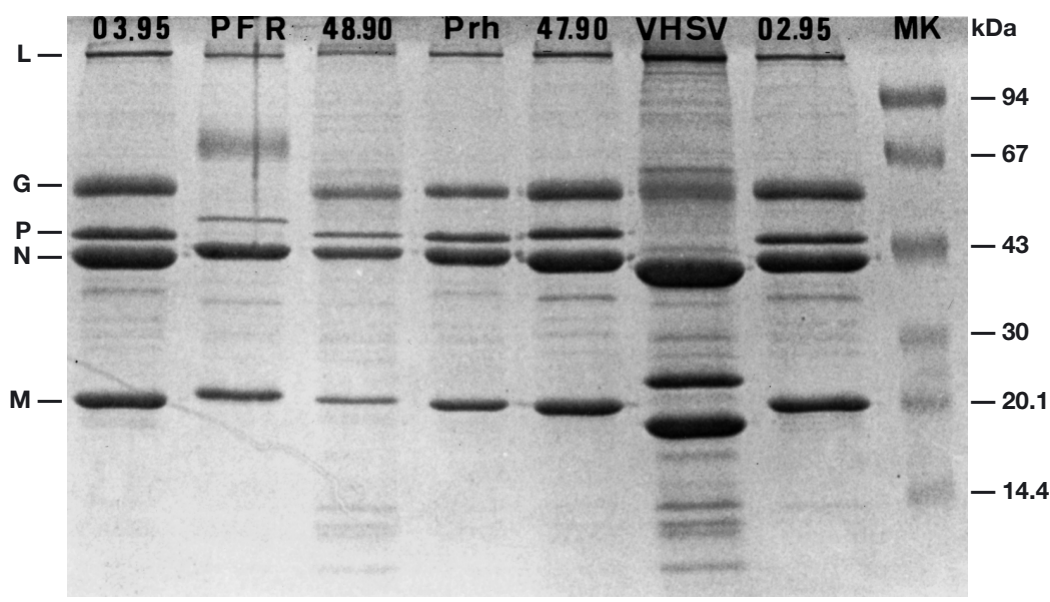

Fig. 3. Electropherogram of purified virus preparations in SDS-PAGE. Identity of each preparation, abbreviated as in Table 1 indicated at top of lanes; Prh: perch rhabdovirus. MK: molecular weight markers. On left, L, G, P, N, M designate viral polypeptides; on right, molecular weights of marker proteins are indicated in $\mathrm{kDa}$ relative mobilities of their $\mathrm{P}$ and $\mathrm{M}$ proteins. The $\mathrm{P}$ protein differed by approximately $4.5 \mathrm{kDa}$ and the $\mathrm{M}$ protein by $1.5 \mathrm{kDa}$ compared to PFRV. When resolved by SDS-PAGE some of the PFRV and SVCV G protein migrates to the appropriate position on the gel $(60.0 \mathrm{kD})$; however, the bulk of the protein migrates much slower than anticipated, which probably reflects different patterns of glycosylation. This slower than normal migration of the $\mathrm{G}$ protein was not observed for Virus Isolates 47.90, 48.90, 02.95, 03.95 or the perch rhabdovirus.

\section{RT-PCR and DNA sequencing}

The amplified region of the viral RNA polymerase gene corresponds to Bases 1610 to 2060 of the vesiculo stomatitis New Jersey virus (VSNJV) L gene nucleotide sequence (GenBank Accession No. M20166). Due to the degenerate nature of the primers used in this study, a small number of non-specific products were also amplified during PCR reactions. However, these were 
easily resolved away from the L gene product during gel electrophoresis and allowed accurate excision of the desired product from the gel. Sequence alignment revealed a high degree of sequence homology between Isolates $02.95,03.95,47.90,48.90$ and the perch rhabdovirus, with between 0 and 19 nucleotide differences (95.7 to $100 \%$ identity) (Fig. 4). In contrast, there were 106 to 110 nucleotide differences ( 75.0 to $75.9 \%$ identity) and 116 to 119 nucleotide differences (72.9 to $73.6 \%$ identity) between these viruses and PFRV and SVCV, respectively, and 92 to 97 nucleotide differences ( 77.9 to $79.1 \%$ identity) compared to the lake trout rhabdovirus (903/87). A high degree of homology (95.0\% identity) was found between the perch rhabdovirus and DK5533, with only 22 nucleotide differences. Phylogenetic analysis revealed 4 genogroups, I-IV, that were supported by bootstrap probabilities of $>99 \%$. PFRV, SVCV and the lake trout rhabdovirus were assigned to 3 of the groups, with all the remaining viruses including DK5533 assigned to the fourth (Fig. 5).

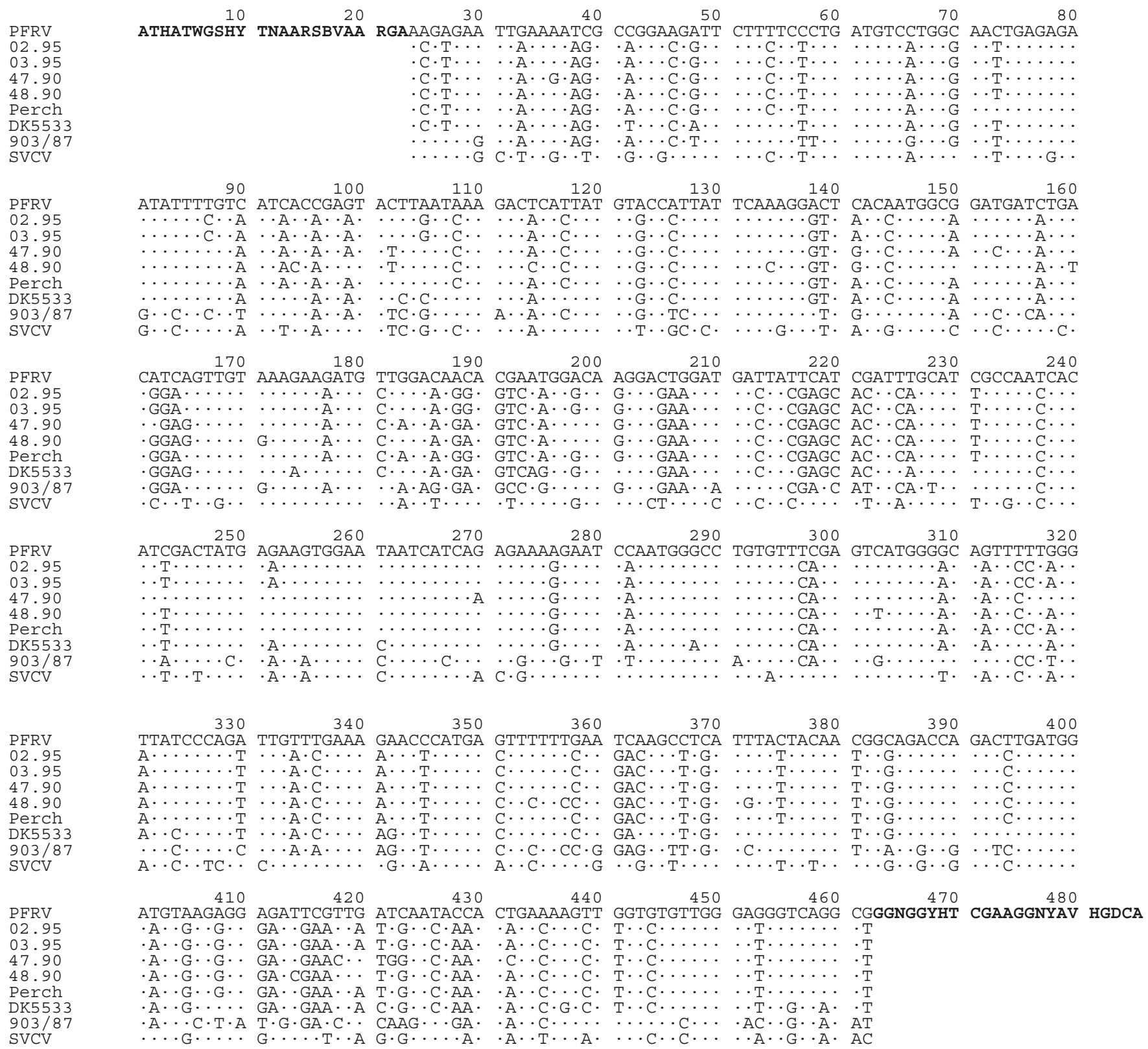

Fig. 4. Nucleic acid alignments of $439 \mathrm{bp}$ partial L gene sequence determined for novel virus isolates, perch rhabdovirus, lake trout rhabdovirus (903/87), pike fry rhabdovirus (PFRV) and spring viraemia of carp virus (SVCV). Primer sequences are in bold-face. Amplified region corresponds to Bases 1610 to 2060 of the VSV New Jersey L-gene nucleotide sequence. $(\cdot)$ indicate positions of sequence identity compared to PFRV nucleotide sequence, and nucleotide differences are illustrated by appropriate IUB code 
A)

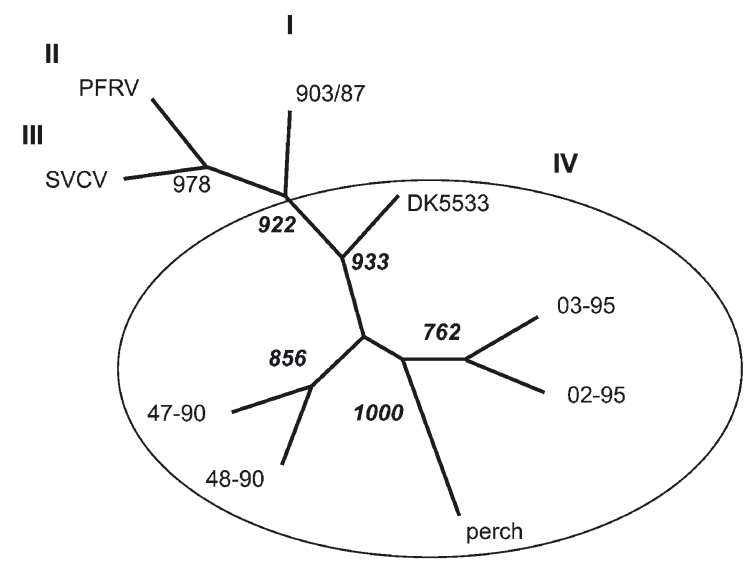

B)

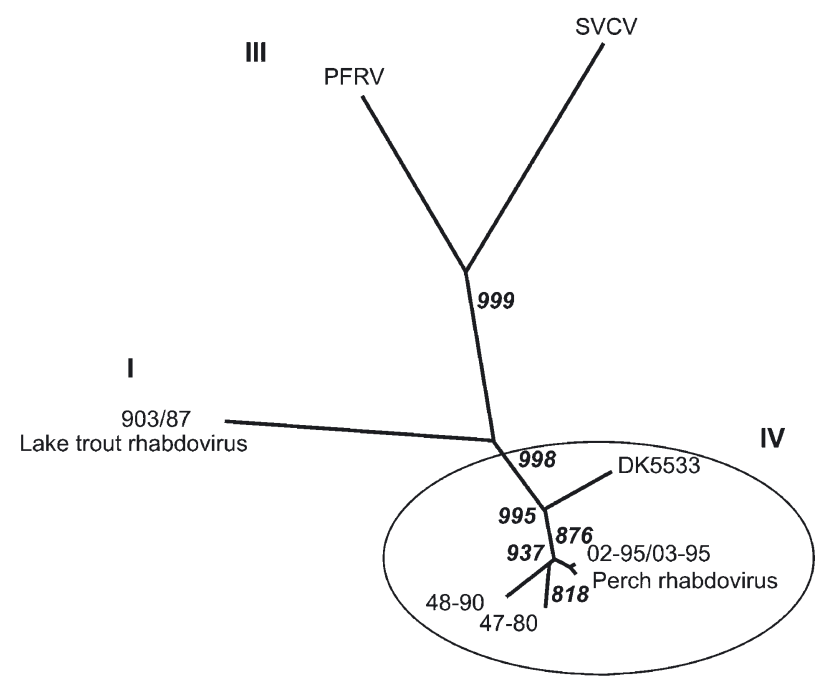

Fig. 5. Unrooted phylogenetic trees generated by maximum parsimony (A) and neighbour-joining (B) analysis of $439 \mathrm{bp}$ partial L-gene sequences of viruses in Table 1. Analyses were made of 1000 bootstrapped data sets, and values $>700$ are shown on the trees. Tree shown for the neighbour-joining DNA distance method was generated using non-bootstrapped analysis to retain branch length information, and the bootstrap values were placed on analogous branches of the tree. Abbreviations as in Table 1

\section{DISCUSSION}

Following the isolation of perch rhabdovirus in France (Dorson et al. 1984) and subsequent isolation of a related virus, 48-90 from pike perch (Nougayrede et al. 1992), antigenically related rhabdoviruses (47-90 and 03-95) were isolated from diseased grayling (M. Morand pers. comm.) and largemouth bass (this study), respectively. The latter was isolated from the same farm site as Isolate 48-90 and a further isolate from perch, 02-95. The same farm site had received fish from the site of the original perch rhabdovirus isolation, suggesting that there may be an epidemiological link between at least 4 of the 5 recorded isolations; since all isolates were associated with mortalities, this could represent an emerging disease problem.

All isolates studied were shown to have the compact morphology associated with vesiculoviruses (Van Regenmortel et al. 2000) as compared to the typically longer novirhabdovirus particles. The polypeptide profiles for Isolates 47-90,48-90, 02-95 and 03-95 were similar to the perch rhabdovirus profile. When compared to other fish rhabdoviruses, they showed greatest similarity to the profile generated for PFRV, with the exception of the mobility of the $\mathrm{P}$ and $\mathrm{M}$ proteins, which differed by approximately 4.5 and $1.5 \mathrm{kDa}$, respectively. Nonetheless, the mobility of the $\mathrm{P}$ protein relative to the $\mathrm{N}$ protein was also typical of the fish vesiculo-type viruses. These findings, together with the observation that antisera raised against the perch rhabdovirus exhibited a significant cross-reaction with Isolates 47-90,48-90, 02-95 and 03-95 in both the neutralisation test and IFAT but failed to react with the PFRV, SVCV and VHSV, suggest that these isolates may represent a novel group of viruses within the fish vesiculo-type virus group.

Neutralisation tests using antisera raised against the perch rhabdovirus, 47-90 and 48-90 provided further resolution. Antisera raised against Isolates 47-90 and 48-90 reacted strongly with the homologous viruses but neutralised the perch rhabdovirus and 03-95 less efficiently, possibly indicating the existence of different serotypes. Indeed, phylogenetic analysis based on a 439 bp fragment of the L gene assigned all the antigenically related viruses to a single genogroup, but also highlighted that while the perch rhabdovirus and Isolates 02-95 and 03-95 are highly conserved ( $\geq 99.2 \%$ identity) at the nucleotide level, there was a higher than expected degree of sequence divergence $(\leq 97 \%$ nucleotide identity) compared to Isolates 47-90 and 48-90. The similarity in sequence between the perch rhabdovirus and Isolates 02-95 and 03-95 is consistent with the possible transmission of the infectious agent during the transfer of perch from the site of the original perch rhadovirus outbreak in 1981; however, there was insufficient nucleotide sequence similarity with Isolate 48-90 (95.7\% identity) to suggest an epidemiological link. There was also a higher degree of sequence divergence (97\% identity) between the perch rhadovirus and Isolate 47-90 than would have been expected had they originated from a single pointsource. A similar level of sequence divergence was observed between VHSV isolates of a common geographical origin (Benmansour et al. 1997, Stone et al. 1997), but was considered sufficiently different for the viruses to have originated from distinct sources within 
that area. The similarity between the perch rhabdovirus and DK5533 was even lower (95\% identity). Phylogenetic analysis based on the deduced amino acid sequence revealed the same 4 genogroups (data not shown), with the novel virus isolates sharing greater than $\geq 97.9$ similarity to perch rhabdovirus and less than $85.6 \%$ similarity to PFRV, SVCV and the laketrout rhabdovirus.

In the absence of any surveillance campaign, the prevalence and yearly incidence of infections due to perch rhabdovirus remain largely unknown. However, the perch rhabdoviruses and serologically related viruses have been isolated in Denmark, Norway, Germany and the Republic of Ireland (Jørgensen et al. 1993, Dannevig et al. 2001), indicating that these viruses may be far more widespread in Europe than the limited number of recorded isolations suggest.

There are only limited data on the pathogenicity of the perch rhabdoviruses (Dorson et al. 1984, Nougayrède et al. 1992), nonetheless, there is some strong evidence to suggest that these viruses pose a serious threat to both cultivated and wild fish populations. The viruses were associated with high mortality in the fish species from which they originated, and in the absence of other pathological agents were considered to be the primary aetiological agent. Infection trials also provide some evidence of the potential threat posed by these viruses. Bath challenge of pike alevins with the perch rhabdovirus and Isolate DK5533 resulted in mortality of up to 51 and $87 \%$, respectively (Dorson et al. 1987, Jørgensen et al. 1993), and pre-adult perch developed clinical symptoms of nervous behaviour following intracranial injection with the perch rhabdovirus (Dorson et al. 1987). A number of virus isolations were, however, made from healthy asymptomatic fish, which suggests that in some species an additional trigger may be required to induce the clinical disease following a natural infection. The disease outbreak in common bream Abramis brama reported by Rowley et al. (2001) is a good example of a situation in which an apparently benign virus can spontaneously produce high levels of mortality in a wild fish population. Isolation of the virus from brown and rainbow trout before the outbreak (Adair \& McLoughlin 1986) and its isolation from asymptomatic bream and roach in the years following the outbreak suggest that the trigger for disease is absent most of the time. Although the trigger has not yet been identified, analyses carried out at the time suggest that on this particular occasion a dramatic decrease in water quality may have played an important role in enhancing the severity of the disease (Rowley et al. 2001).

In summary, this study has identified a number of variants of the perch rhabdovirus. These viruses appear antigenically, biochemically and genetically distinct from PRFV and SVCV (which have been historically considered as being the only rhabdoviral pathogens of non-salmonid fish) and are also genetically distinct from the lake trout rhabdoviruses typified by Isolate 903/87. These viruses have on occasion exhibited a high level of pathogenicity, are possibly more prevalent in Europe than it was previously thought, and as such may pose a significant threat to both cultivated and wild freshwater-fish populations.

Acknowledgements. This work was supported in part by INRA, France, and DEFRA, UK (contract nos. F1136 and F1152). We are indebted to the following persons for kindly supplying virus, antiserum and/or case histories: Dr. J. Castric of the Agence Française de Sécurité Sanitaire des aliments (AFSSA) in Plouzané, Finistère, France; Dr. M. Morand of the Laboratoire Départemental d'Analyses (LDA) in Lons-leSaulnier, France; Dr. P. Nougayrède of the LDA in Mont-deMarsan, Landes, France; Dr. M. Dorson of INRA and Dr. N. J. Olesen of the National Veterinary Laboratory in Aarhus, Denmark. The skill of B. Nicolas from the Communication Unit of the INRA Research Centre of Jouy-en-Josas, who produced the micrograph prints, is highly appreciated.

\section{LITERATURE CITED}

Adair BM, McLoughlin M (1986) Isolation of pike fry rhabdovirus from brown trout (Salmo trutta). Bull Eur Assoc Fish Pathol 6:85-86

Archetti I, Horsfall FL (1950) Persistent antigenic variation of influenza viruses after incomplete neutralisation in vivo with heterologous immune serum. J Exp Med 92:441-462

Benmansour A, Bascuro B, Monnier AF, Vende P, Winton JR, de Kinkelin P (1997) Sequence variation of the glycoprotein gene identifies three distinct lineages within field isolates of viral haemorrhagic septicaemia virus, a fish rhabdovirus. J Gen Virol 78:2837-2846

Betts AM, Stone DM (2000) Nucleotide sequence analysis of the entire coding regions of virulent and avirulent strains of viral haemorrhagic septicaemia virus. Virus Genes 20: $259-262$

Björklund HV, Olesen NJ, Jørgensen PEV (1994) Biophysical and serological characterisation of rhabdovirus 903/87 isolated from the European lake trout Salmo trutta lacustris. Dis Aquat Org 19:21-26

Bradford MM (1976) a rapid and sensitive method for the quantification of microgramme quantities of proteins using the principle of protein-dye binding. Analyt Biochem 72: $248-254$

Castric J (1997) Viral diseases in fish mariculture. Bull Eur Assoc Fish Pathol 17:220-228

Dannevig BH, Olesen NJ, Jentoft S, Kvellestad A, Taksdal T, Håstein $T$ (2001) The first isolation of a rhabdovirus from perch (Perca fluviatilis) in Norway. Bull Eur Assoc Fish Pathol 21:145-153

de Kinkelin P, Bootsma R, Galimard B (1973) Isolation and identification of the causative agent of pike 'red disease'. Nature 241:465-467

de Kinkelin P, Michel C, Ghittino P (1985) Precis de pathologie des poissons. Institut National de la Recherche Agronomique, Paris

Dorson M, Torchy C (1979) Complement dependent neutrali- 
sation of Egtved virus by trout antibodies. J Fish Dis 2: 345-347

Dorson M, Torchy C, Chilmonczyk S, Kinkelin P de, Michel C (1984) A rhabdovirus pathogenic for perch (Perca fluviatilis L.): isolation and preliminary study. J Fish Dis 7: $241-245$

Dorson M, de Kinkelin P, Torchy C, Monge D (1987) Sensibilité du brochet (Esox lucius) à différents virus de salmonidés (NPI, SHV, NHI) et au rhabdovirus de la perche. Bull Fr Pêche Piscic 307:91-101

Felsenstein (1989) PHYLIP: phylogeny inference package Version 3.5. Cladistics 5:164-166

Fijan NZ, Sulimanovic PD, Zwillenberg LO (1971) Isolation of the viral causative agent from the acute form of infectious dropsy of carp. Vet Arh 41:125-138

Fijan N, Sulimanovic D, Béarzotti M, Muzinic D, Zwillenberg LO, Chilmonczyk S, Vautherot JF, de Kinkelin P (1983) Some properties of the Epithelioma papulosum cyprini (EPC) cell line from carp (Cyprinus carpio). Ann Inst Pasteur Virol 134E:207-220

Hetrick FM, Hedrick RP (1993) Annu Rev Fish Dis 3:187-207

Higgins DG, Sharp PM (1989) Fast and sensitive multiple sequence alignments on a microcomputer. CABIOS 2: 151-153

Hill BJ, Way K (1995) Serological classification of infectious pancreatic necrosis virus (IPN) and other aquatic birnaviruses. Annu Rev Fish Dis 5:55-77

Johansson T, Nylund S, Olesen NJ, Björklund H (2001) Molecular characterisation of the nucleocapsid protein gene, glycoprotein gene and gene junctions of rhabdovirus 903/87, a novel fish pathogenic rhabdovirus. Virus Res 80: $11-22$

Jørgensen PEV, Olesen NJ, Ahne W, Wahli T, Meier W (1993) Isolation of a previously undescribed virus from pike Esox lucius. Dis Aquat Org 16:171-179

Koski P, Hill B, Way K, Neuvonen E, Rintamäki P (1992) A rhabdovirus isolated from brown trout (Salmo trutta m. lacustris (L.)) with lesions in parenchymatous organs. Bull Eur Assoc Fish Pathol 12:177-180

Laemmli UK (1970) Cleavage of structural proteins during the assembly of the head of bacteriophage T4. Nature 227: 680-685

Le Berre M, Kinkelin P de, Metzger A (1977) Identification sérologique des rhabdovirus des salmonidés. Bull Off Int Epizoot 87:391-393

Le Mercier P, Jacob Y, Tordo N (1997) The complete Mokola virus genome sequence: structure of the RNA-dependent RNA polymerase. J Gen Virol 78:1571-1576

Nougayrède $\mathrm{P}$, de Kinkelin $\mathrm{P}$, Chilmonczyk, Vuillaume A (1992) Isolation of a rhabdovirus from the pike-perch Stizostedium lucioperca L 1758. Bull Eur Assoc Fish Path 12:5-7

Poch O, Blumberg BM, Bougueleret L, Tordo N (1990) Sequence comparison of five polymerases (L proteins) of unsegmented negative-strand RNA viruses: theoretical assignment of functional domains. J Gen Virol 71: 1153-1162

Rowley H, Graham DA, Campbell S, Way K, Stone DM, Curran WL, Bryson DG (2001) Isolation and characterisation of rhabdovirus from wild common bream Abramis brama, roach Ritilus rutilus, farmed brown trout Salmo trutta and rainbow trout Oncorhynchus mykiss in Northern Ireland. Dis Aquat Org 48:7-15

Sambrook J, Fritsch EF, Maniatis T (1989) Molecular cloning: a laboratory manual, 2nd edn. Cold Spring Harbor Laboratory, NY

Stoker M, MacPherson I (1961) Studies on transformation of hamster cells by polyoma virus in vitro. Virology 14 : 359-370

Stone DM, Way K, Dixon PF (1997) Nucleotide sequence of the glycoprotein gene of viral haemorrhagic septicaemia (VHS) viruses from different geographic areas: a link between VHS in farmed fish species and viruses isolated from North Sea cod (Gadus morhua L.). J Gen Virol 78: $1319-1326$

Van Regenmortel MHV, Fauquet CM, Bishop DHL, Carstens EB (2000) Family Rhabdoviridae. In: Virus taxonomy. Seventh Report of the International Committee on Taxonomy of Viruses. Academic Press, London, p 563-583

Wolf K (1988) Fish viruses and fish viral diseases. Cornell University Press, Ithaca, NY

Wolf K, Quimby MC (1962) Established eurythermic line of fish cell in vitro. Science 135(3508):1065-1066

Wolf K, Gravell M, Malsberger RG (1966) Lymphocystis virus: isolation and propagation in a centrarchid fish cell line. Science 151:1004-1005

Submitted: December 15, 2001; Accepted: August 1, 2003 Proofs received from author(s): December 12, 2003
Editorial responsibility: Jo-Ann Leong,

Kaneohe, Hawaii, USA 